TITLE:

A REVISION OF THE NOMENCLATURE OF THE FAMILY NEPHTHEIDAE (OCTOCORALLIA

: ALCYONACEA) -III. A NEW GENUS CORONEPHTHYA FOR A UNIQUE OCTOCORAL PREVIOUSLY ASSIGNED TO THE GENERA DENDRONEPHTHYA OR STEREONEPHTHYA-

\author{
$\operatorname{AUTHOR}(\mathrm{S})$ : \\ Utinomi, Huzio
}

CITATION:

Utinomi, HuZio. A REVISION OF THE NOMENCLATURE OF THE FAMILY NEPHTHEIDAE (OCTOCORALLIA: ALCYONACEA)III. ANEW GENUS CORONEPHTHYA FOR A UNIQUE OCTOCORAL PREVIOUSLY ASSIGNED TO THE GENERA

DENDRONEPHTHYA OR STEREONEPHTHYA. PUBLICATIONS OF THE SETO MARINE BIOLOGICAL LABORATORY 1966, 14(3): $207-218$

ISSUE DATE:

1966-07-20

URL:

http://hdl.handle.net/2433/175437

RIGHT: 


\title{
A REVISION OF THE NOMENCLATURE OF THE FAMILY NEPHTHEIDAE (OCTOCORALLIA : ALCYONACEA)
III. A NEW GENUS CORONEPHTHYA FOR A UNIQUE OCTOCORAL PREVIOUSLY ASSIGNED TO THE GENERA DENDRONEPHTHYA OR STEREONEPHTHYA

\author{
HuzIo U'TINOMI
}

Seto Marine Biological Laboratory, Sirahama

With Plate XI and 3 Text-figures

During the course of working on the octocorals collected by His Majesty the Emperor of Japan in Sagami Bay, I have found twice a unique alcyonarian apparently referable to Dendronephthya magnacantha Nutring (1912) which was collected by the U. S. Fisheries Steamer "Albatross" from Japanese waters during her cruise of 1906. Fortunately I have been able to re-examine the holotype specimen of this species for comparison through the generosity of the United States National Museum and Dr. Frederick M. BAYER who was at that time in the care of the "Albatross" collections deposited in that Museum.

A further search for the literature enabled me to suggest that the former may be congeneric with Stereonephthya macrospiculata Thomson and Mackinnon (1910) collected by the Percy Sladen Trust Expedition to the Indian Ocean in 1906 from off Salomon Islands, although I had no occasion actually to see the type specimen of the latter.

I am particularly indebted to the authorities of the U. S. National Museum, Washington, D. C. and Dr. Frederick M. BAYER, now at the Institute of Marine Science, of the University of Miami, Miami, Florida for the loan of the type specimen of the said alcyonarian as well as the other materials contained in the "Albatross" Collections for identification. Furthermore I must express my best gratitude to $\mathrm{Mr}$. Hatsuki Tsujimura, a biologist in the service of His Majesty's Biological Laboratory for the arrangement of studying His Majesty's vast collections from Sagami Bay.

\section{Redescription of the Type Specimen of Dendronephthya magnacantha NuTTING Deposited in the U. S. National Museum}

The following description and illustrations (Fig. 1) are based upon a fragment

1) Contributions from the Seto Marine Biological Laboratory, No. 458.

Publ. Seto Mar. Biol. Lab., XIV (3), 207-218, 1966. (Article 17) 
cut off from the type specimen registered as Cat. No. 30090, U.S.N.M.

Material Examined. A part of the polyparium and a part of the expanded base.

Description. The polyps in the polyparium are closely grouped together on a few bosses and each one removed is large. The polyp-head is placed perpendicularly at the distal end of slender anthostele and measures about $1-1.8 \mathrm{~mm}$ in diameter and slightly longer, showing a conical shape. It is colored chocolate-brown and armed with a few white, robust spicules in eight points of only one converging row and below these larger spicules are disposed in one to three transverse collaret rows; sometimes one or two smaller ones may occur at the base of the point pair additionally. Between the rows of point pairs there is no intermediate spicules at all. All the tentacles here examined are fully contracted, but flat, rodlike spicules closely set in 2 rows can be seen on the dorsum. The convex side of the anthostele opposite to the polyp-head is supported by a bundle of a few larger spicules, and its uppermost end slightly projects beyond the polyp-head. The lateral and ventral sides of the anthostele below the polyp-head are devoid of spicules. If applying the anthocodial grade and formula proposed by Sherifrs (1922) for the genus Dendronephthya, the anthocodial armature mentioned above may be expressed as follows:

$$
\mathrm{VI}=1 \mathrm{P}+(1-3) \mathrm{Gr}+\text { strong S.B. }+0 \mathrm{M}
$$

The lower part of the stem is overlaid with extraordinarily large spicules vertically disposed. Similar spicules are found on the expanded base. The larger ones attain as much as $4.5 \mathrm{~mm}$ long and $0.5 \mathrm{~mm}$ wide. They are much tuberculated spindles with blunt ends. Anthocodial spicules are also tuberculated, bluntly ended spindles, either straight or slightly bent, measuring as follows:

Point spicules $\quad 1.8 \mathrm{~mm} \times 0.2 \mathrm{~mm}$

Collaret spicules $2.3 \mathrm{~mm} \times 0.2 \mathrm{~mm}$

S. B. spicules $\quad 3.5 \mathrm{~mm} \times 0.4 \mathrm{~mm}$

Localities. Sata-Misaki Light, N. $21^{\circ}$ E., 5.7 miles, 103 fathoms (Type); OseSaki, S. $8^{\circ}$ W. 1.8 miles, 108 fathoms. All are located in the west of Kyusyu, western Japan.

\section{Description of Materials Deposited in His Majesty's Biological Laboratory}

Among the octocorallian collections made by His Majesty the Emperor from Sagami Bay three specimens apparently referable to the above-mentioned Dendronephthya magnacantha NutTing are found.

1) Material Examined. A single specimen registered as Coel. Sp. No. 57, B.L.I.H ${ }^{2)}$. Collected at Amadaiba, east of Sagami Bay, 50 fms. on Jan. 20, 1935. (Plate XI, fig. 1)

2) B.L. I. H. - Biological Laboratory of the Imperial Household. 
Description (Fig. 2). The colony is rather elongate-conical in appearance, consisting of a barren rigid stalk gently tapered upward and a polyp-bearing upper part. The total height is $35 \mathrm{~mm}$ and the width of the polyparium is about $25 \mathrm{~mm}$.
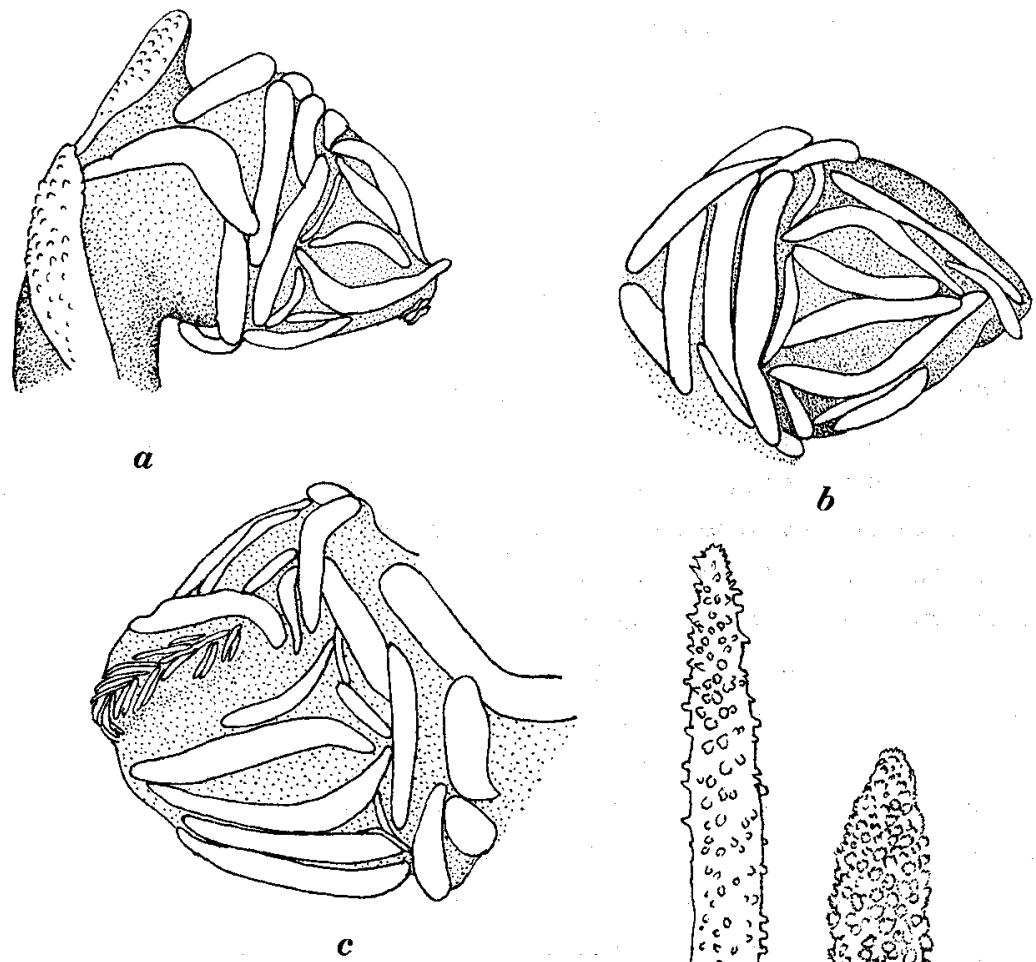

$b$

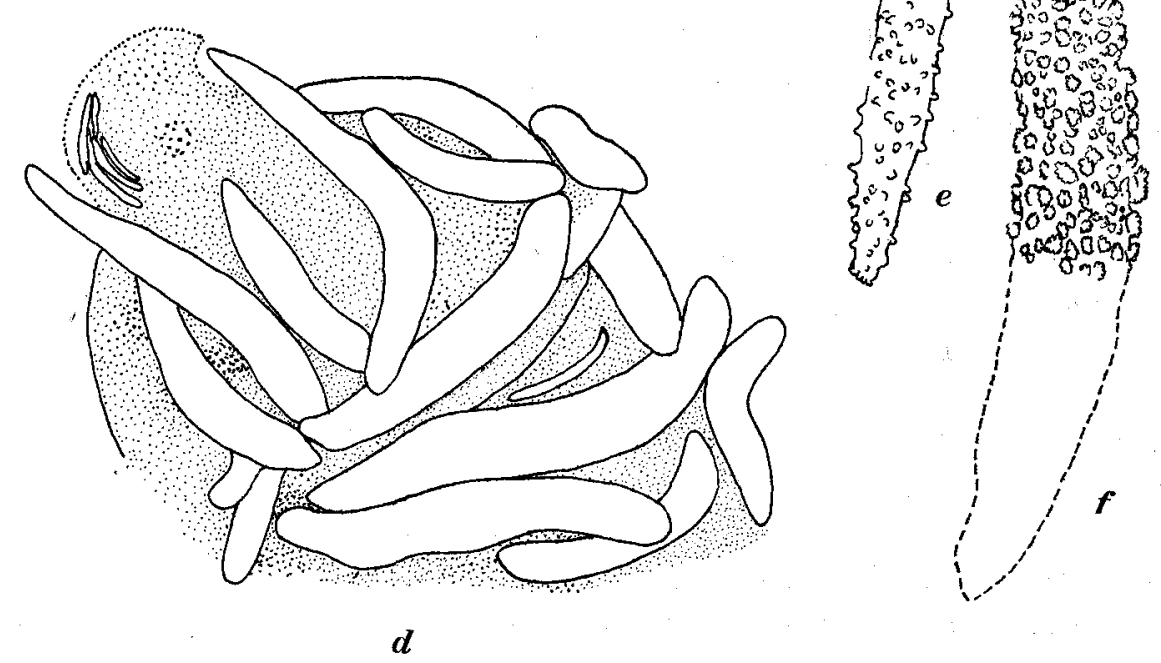

Fig. 1. Holotype of Dendronephthya magnacantha Nutring. Cat. No. 30090, U.S.N.M. $a-d$, Polyp-head; $e$, spicule from polyp-stalk; $f$, spicule from stem cortex. $[a-d, \times 25 ; e-f, \times 54]$ 
The stalk lacking polyps is about $15 \mathrm{~mm}$ long and about $9 \mathrm{~mm}$ in diameter. Its cortex is densely packed with stout white spicules vertically, and above this a number of large polyps surround the tip of the stalk horizontally. These cortical spicules attain about $8 \mathrm{~mm}$ in length and about $0.75 \mathrm{~mm}$ in width. They are all heavily tuberculated spindles bluntly ended. The base of the stalk is expanded and coated wholly with silicious sponges. No stolons are found. The mode of growth, as shown by a photograph, is never arborescent, but crown-like or tower-shaped.

In the upper half of the stem the polyps are densely grouped together on a few low bosses, while a little way down from the tip the polyps are extremely larger in size with longer stalk and are borne singly, encircling the upper part of the stalk. Between them large spicules similar to those of the barren stalk are longitudinally disposed, though sparse.

The polyps, especially in the lower part of the polyparium, are bent downwards and their head is thus directed adaxially. The larger polyp-head measures $3 \mathrm{~mm}$ long and $2.5 \mathrm{~mm}$ wide; when extended, each one (anthostele and anthocodia combined together) may attain about $10 \mathrm{~mm}$ in length. The anthostele is supported by a few number of stout spicules, quite similar to the cortical spicules of the stem, on the abaxial side, abruptly bending at the tip. The adaxial and lateral sides of the anthostele are, however, wholly nude from base to tip. These anthostelar S.B. spicules may attain $6 \mathrm{~mm}$ long and $0.8 \mathrm{~mm}$ wide.

The anthocodial armature is exactly the same as stated for the Albatross material. The point spicules are only one-paired, rarely with additional one in 8 rows; they measure $1.2 \mathrm{~mm}$ long and $0.12 \mathrm{~mm}$ wide. Below the point pairs 3 rows of straight spindles are placed transversely, forming together a collaret ring.

The tentacles, when fully extended, are very long, 2.5-3 $\mathrm{mm}$. They bear about 10 pairs of moniliform pinnules on both sides and many rodlike bent spicules on the dorsum; spicules in the proximal part are arranged longitudinally, while those in the distal part transversely.

The color of the stem overlaid with white spicules is ivory buff. The polyp-head itself is, however, chocolate-brown.

2) Material Examined. Two colonies attached to a rock debris together with polychaete tubes and encrusting bryozoans, registered as Coel. No. 903, B.L.I.H. Collected at Okinoyama, SE of Sagami Bay, 85-90 m deep, on Jan. 24, 1965. (Plate XI, fig. 2)

Description (Fig. 3). Both colonies showing similar mode of growth have a membranously expanded base from which arises a stout, cylindrical stem, about $7-8 \mathrm{~mm}$ in diameter. The stem is buffy yellow in alcohol and overlaid thickly with large spicules vertically. The total height up to the uppermost polyps is $35-36 \mathrm{~mm}$, of which the upper half (ca. $15 \mathrm{~mm}$ long) is apparently conical, unbranched and surrounded with a number of large polyps of chocolate-brown color in groups.

The upper part of the stem (i.e. the polyparium) and the lower barren part (i.e. 
the stalk) are not essentially differentiated in spiculation, excepting that in the polyparium only the cortical spicules around the base of polyp stalks are rather sparse due to the lack of space.

At the tip of the polyparium the polyps are somewhat shorter and much crowded
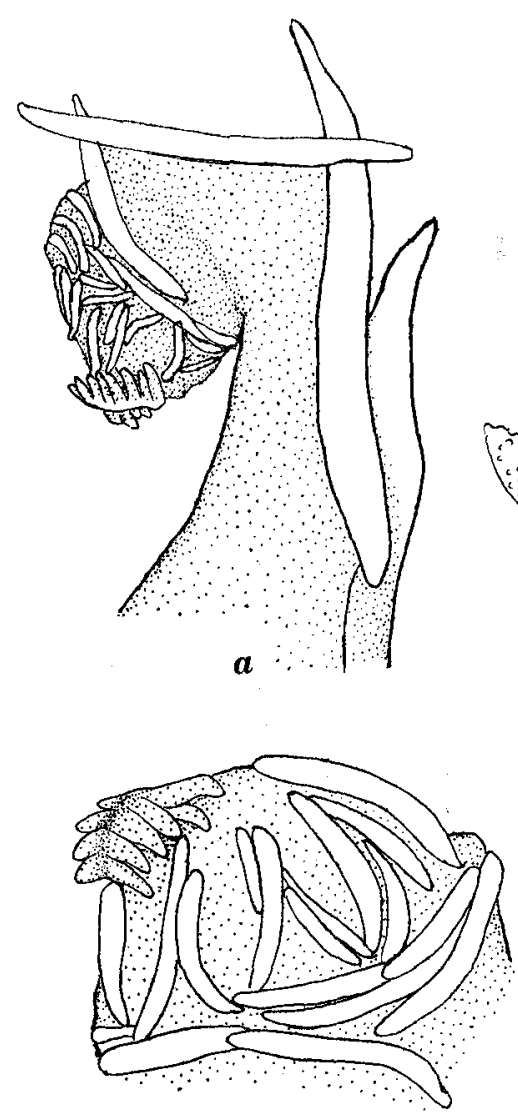

b
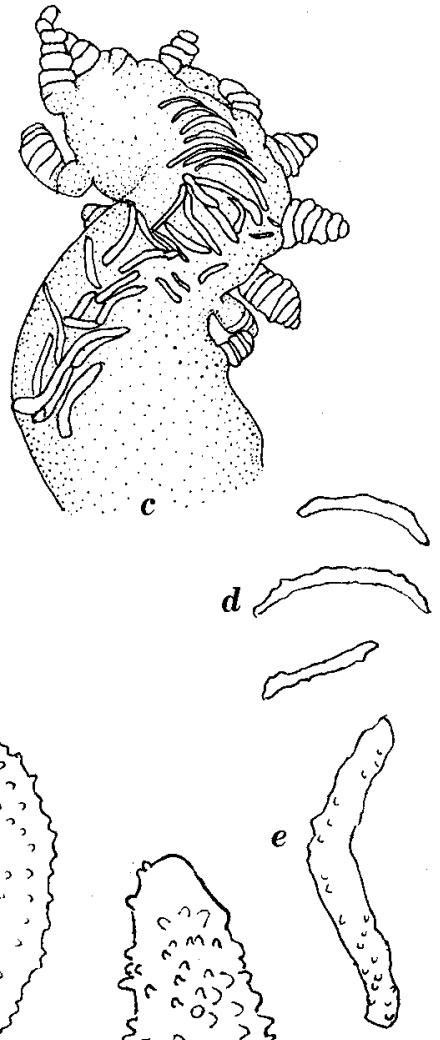

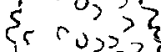

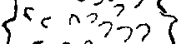

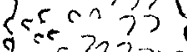

Scres 50$\rangle)$

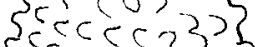

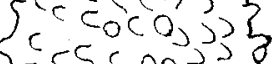

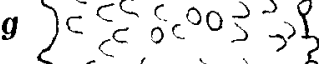

$\left\{\begin{array}{ll}c_{c} & 000\end{array}\right)$

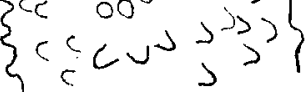

Fig. 2. Coronephthya macrospiculata (Thomson and MAckinnon), comb. nov. from Amadaiba, east of Sagami Bay. Coel. No. 57, B.L.I.H.

$a$, Tip of polyp; $b$, polyp-head; $c$, extended tentacle, aboral side; $d$, spicules in the distal part of tentacle; $e$, spicule in the proximal part of tentacle; $f$, point spicule; $g$, part of spicule from polyp-stalk. $[a, \times 10 ; b-c, \times 34 ; d-g, \times 80]$ 
together. Around the lower part of the polyparium the polyps are largely arisen singly, hanging down, and each of them is supported by a long crooked stalk armoured with 5-10 stout spicules on its dorsal or abaxial side, projecting from the stem cortex.
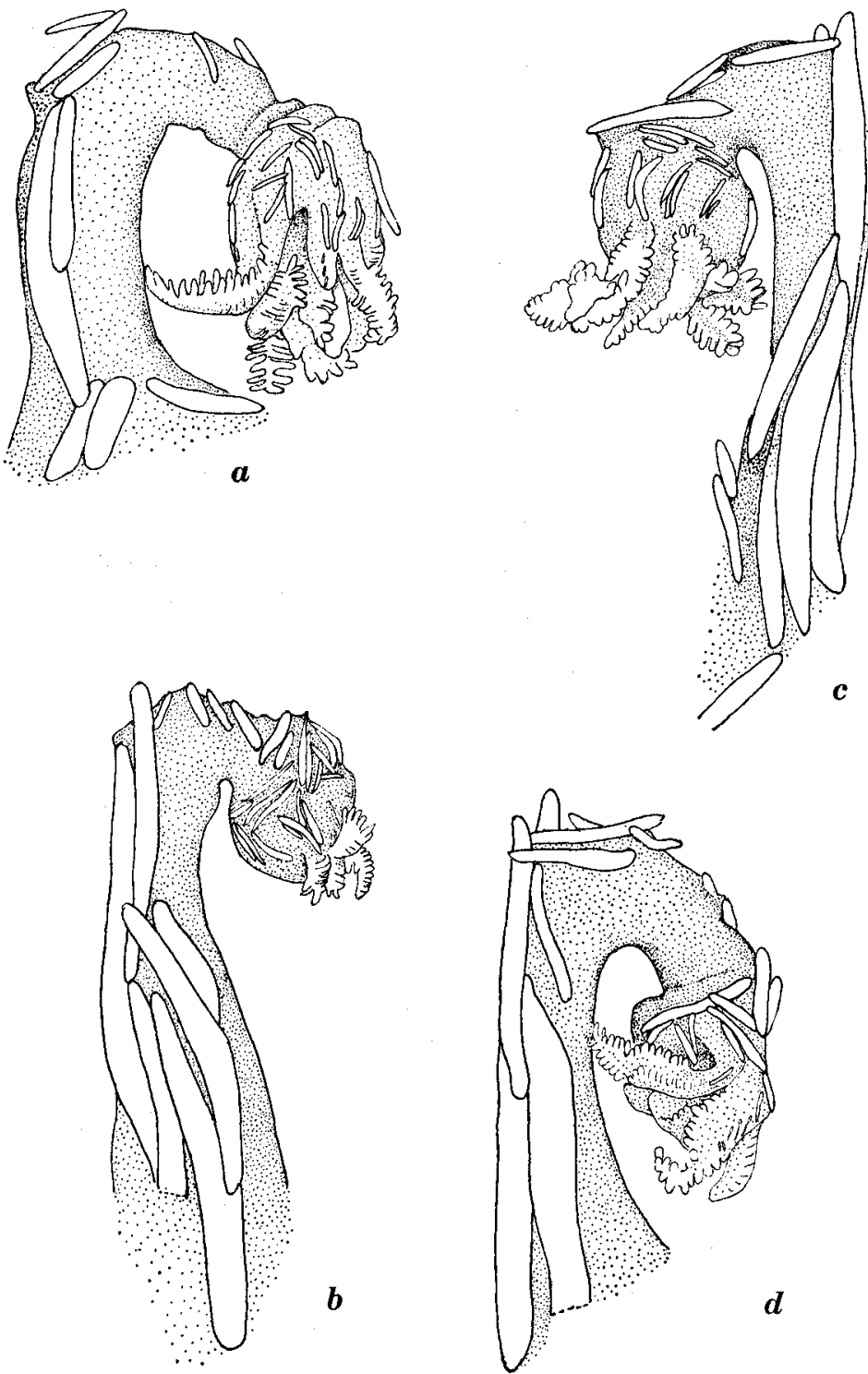

Fig. 3. Coronephthya macrospiculata (Thomson and Mackinnon), comb. nov. from Okinoyama, SE of Sagami Bay. Coel. No. 903, B.L.I.H.

$a$, Extended polyp in the upper part of polyparium, where polyps are grouped together; $b-d$, extended polyps in the lower part of polyparium, where polyps are arisen singly. [All $\times 12]$ 
These supporting spicules are disposed longitudinally in a slight entheathing form up to the tip of the stalk, the uppermost one or two only slightly projecting beyond the neck zone continued from the hanging down polyp-head. The ventral or adaxial side of the polyp-stalk is entirely devoid of spicules. The dorsal or apical side of the retrovertible neck zone is also armoured with a few small spicules biserially up to the polyp-head.

In the lower whorls of polyps the mouth of polyps is thus opened upward in situ and the tentacles are so folded around the mouth in the contracted condition. The tentacles fully extended are very large, and armed with tiny rodlike spicules and moniliform pinnules as mentioned above.

The interior of the stem is apparently devoid of spicules, only provided with solenia and longitudinal muscles on canal-walls.

\section{Measurements.}

Polyp-stalk supported by a bundle of spicules $-7 \mathrm{~mm}$ long, $1-1.2 \mathrm{~mm}$ wide (in the lower whorls); $3 \mathrm{~mm}$ long, $0.7-1 \mathrm{~mm}$ wide; $4-5 \mathrm{~mm}$ long, $1 \mathrm{~mm}$ wide (in the upper whorls grouped together).

Polyp-head (excluding the neck zone) $-1.5 \mathrm{~mm}$ long, $1.5 \mathrm{~mm}$ wide; $3 \mathrm{~mm}$ long, $1.5 \mathrm{~mm}$ wide.

Tentacles extended $-1.5 \mathrm{~mm}$ long.

Spicules from the cortex of stalk-2 $\mathrm{mm} \times 0.26 \mathrm{~mm} ; 3.5 \mathrm{~mm} \times 0.4 \mathrm{~mm}$.

Spicules from the cortex of polyparium-2.35 $\mathrm{mm} \times 0.27 \mathrm{~mm} ; 2.7 \mathrm{~mm} \times 0.3 \mathrm{~mm}$. Spicules from the polyp-stalk (S.B.) $-3 \mathrm{~mm} \times 0.3 \mathrm{~mm} ; 3.35 \mathrm{~mm} \times 0.3 \mathrm{~mm} ; 3.8 \mathrm{~mm} \times$

$0.4 \mathrm{~mm}$.

\section{Discussion on Synonymy}

As mentioned above, the three materials collected by His Majesty the Emperor from Sagami Bay, eastern Japan, are undoubtedly referable to Dendronephthya magnacantha formerly collected by the "Albatross" Exploring Cruise to Japanese waters (1906) from two stations lying at the west of Kyusyu, western Japan, and described by Nutring (1912) with three figures.

Prior to this date, an apparently similar species was obtained by the Percy Sladen Trust Expedition to the Indian Ocean (1905) from off Salomon Islands at the depth of 120-150 fms. and then described by J. A. Thomson and Doris L. Mackinnon (1910) under the name Stereonephthya macrospiculata.

According to NutTing's original description, the type specimen of Dendronephthya magnacantha is a small colony, $21 \mathrm{~mm}$ high and $10 \mathrm{~mm}$ wide, arisen from a broadly expanded base. However, details of the colony form have not been mentioned in text, whether the polyp-bearing upper part of the stem is branched or not. But the photograph given by him (P1. 2, fig. 2) is enough to prove that it is clearly conical in form, covered wholly with polyps and large spicules all round the upper part of the 
stem. As the remarks he mentions only "This species is very different from any other Dendronephthya in the collection, and is quite striking in color, the white spicules being well set off in contrast with the buffy and chocolate color of the stalks and polyp heads."

On the other hand, Stereonephthya macrospiculata seems to be more or less large, being $10-30 \mathrm{~mm}$ in height and $12-15 \mathrm{~mm}$ in diameter. Inferring from a figure given by Thomson and Mackinnon (1910, Pl. 9, fig. 8), the polyparium seems to be unbranched, though they mention as "Above the down-rolled collar-like expansion come off several branches like great jagged thorns, which either bear one terminal polyp or else split up into a group of sharp, polyp-bearing twigs."

This is apparently a misleading note, since, as far as I have confirmed from an examination on the materials obtained from Sagami Bay, the lower part of the polyparium is encircled by the down-rolled extremely long polyps which are arisen directly from the stem itself, either singly or in groups; sometimes one large polyp is accompanied with a number of undeveloped polyp-buds around its base and supported by a bundle of large erect spicules. Thus, the note "the existence of a downrolled collar-shaped expansoin" seems to be a little exaggerative.

Thomson and Mackinnon referred this species to the genus Stereonephthya instead of Dendronephthya on account of polyps springing directly from the stem or branches and of the polyp-heads hanging down at the tip of the polyp-stalk.

As formerly affiliated by these authors, the present alcyonarian is clearly related to the genera Dendronephthya and Stereonephthya, both established by KüKenthaL (1905) and generally used by most of later authors, in the shape of polyps supported by a bundle of stout spicules in an entheathing form.

In the rigid consistency of the stalk cortex with huge spindles vertically disposed, this alcyonarian somewhat resembles Nidalia of the Nidaliidae (=Siphonogorgiidae auct.) and Studeriotes of the Viguieriotidae (= Fasciculariidae), but differs in certain respects peculiar to either of them.

As generally recognized, most of the nephtheids show bushy or arborescent growth form with the non-retractile polyps arranged in groups or bundles or singly. Among the group, Dendronephthya (including here Spongodes, Roxasia and Morchellana of Tixier-Durivault and Prevorsek)and Steronephthya, are both bushy or arborescent in the growth form of the polyparium and bear many small polyps supported by a strong bundle of spicules which generally projects by far beyond the terminal head, giving the colony a very spiny appearance (cf. Roxas, 1933; MAGFADYen, 1936; UTINOMI, 1954).

In the present alcyonarian, however, the colony is not so spiny in appearance, but characterized by an unbranched, rather conical in outline, polyparium, covered with extremely large polyps either in groups or singly. And the sterile lower part of the stem arisen from an expanded base is cylindrical and overlaid by huge spicules vertically disposed. 
As to the spiculation in comparison with the ordinary Dendronephthya and Stereonephthya it should be noted from the evolutionary aspect that the polyps are extraordinarily large, consisting of a down-rolled anthocodia and a very long anthostele connected by a long retroversible neck zone, and they are armed with a few number of stout spicules. The anthostelar spiculation is a direct continuation of cortical spiculation of the stem and distinctly separated from the anthocodial spiculation. In the former spiculation, the supporting spicules on the abaxial side are stouter but fewer in number, forming a sheaf of narrower entheathing type than that of Stereonephthya, and no spicules are found on the adaxial side. In the latter spiculation, the reduction of the number of spicules in the point pairs (namely, only one pair) and the formation of the complete transverse rows (namely, only 3 ) in the collaret, represent also an evolved or specialized feature for this alcyonarian within the nephtheid group.

As stated above, the polyparium and spiculation of this alcyonarian seem to be too unique to include within either of the genera Dendronephthya and Stereonephthya. For these reasons I am obliged to establish a new genus for this alcyonarian. As the specific name THomson and Mackinnon's macrospiculata precedes Nutring's magnacantha.

\section{Coronephthya ${ }^{3)}$, new genus}

(Japanese name: Ookan-tosaka)

Dendronephthya (pars), KüKENTHAL, 1905.

Stereonephthya (pars), KÜKENTHAL, 1905.

Coronephthya (nomen nudum), Utinomi, 1962.

Diagnosis: Small unbranched, crown-like nephtheids arisen from an expanded base. Polyps densely packed together in groups or singly on conical tip of rigid cylindrical stem overlaid with stout, tuberculated spindles vertically disposed. Each polyp very large, non-retractile and supported by a long bundle of large spicules similar to cortical ones on stem, longitudinally disposed on abaxial side, continuing up to abaxial side of neck zone of down-rolled anthocodia as biserial rows of rodlets. Canal-walls thin and lack spicules.

Type Species: Here designated by monotypy.

\section{Coronephthya macrospiculata (THOMSON and MACKINNON), new combination}

3) This generic name is feminine and is compounded of Nephthya (usually used for nephtheid alcyonarians) and the prefix "corona or crown" in abbreviated form. 


\section{Synonyms:}

1910 Stereonephthya macrospiculata: Thomson and Mackinnon, Alcyonarians of Percy Sladen Trust Expedition, Trans. Linn. Soc. London, Zool., XIII (8), p.186, pl. 9, fig. $8 ;$ pl. 14, fig. 8.

1912 Dendronephthya magnacantha: Nutring, Descriptions of the Alcyonaria collected by the “Albatross," etc. Proc. U.S. Natl. Mus., 43 (1923), p. 16, pl. 2, figs. 2-2a; pl. 17, fig. 5.

1960 Roxasia magnacantha: Tixier-Durivault et Prevorsex, Le genre Roxasia (Alcyonaria, Nephtheidae), Spolia Zool. Musei Hauniensis, XVIII. p. 292 (as "species incertae sedis," no new record).

1962 Coronephthya macrospiculata: Utrnom, Preliminary list of octocorals of Sagami Bay. Publ. Seto Mar. Biol. Lab., X (1), p. 107 (listed only).

Nec 1931 Stereonephthya macrospiculata: Thomson and Dean, The Alcyonacea of the Siboga Expedition, with an addendum to the Gorgonacea, Siboga-Expeditie, mon. 13d, p. 146, pl. 7, fig. 7. (Seemingly this may be a kind of Paraspongodes, close to P. crassa Kứx.).

Diagnosis: As for the genus.

Distribution: Off Salomon Islands, Indian Ocean, 120-150 fms.; off Sata Misaki Light, 103 fms., Ose Saki, 108 fms. all west of Kyusyu, western Japan; Sagami Bay, eastern Japan, 85-90 $\mathrm{m}$ and $50 \mathrm{fms}$.

\section{REFERENGES}

KÜkenthal, W. 1905. Versuch einer Revision der Alcyonarien. II. Die Familie der Nephthyiden. 2. Teil. Die Gattungen Dendronephthya n. g. und Stereonephthya n. g. Zool. Jahrb. Abt. Syst., vol. 21, no. 5-6, pp. 503-726, pls. 26-32.

Macfadyen, L. M. I. 1936. Alcyonaria (Stolonifera, Alcyonacea, Telestacea and Gorgonacea). Sci. Rep. Gr. Barrier Reef Exped. 1928-29, vol. 5, no. 2, pp. 19-71, pls. 1-5. London.

Nutring, Charles C. 1912. Descriptions of the Alcyonaria collected by the U.S.Fisheries steamer "Albatross," mainly in Japanese waters, during 1906. Proc. U.S. Natl. Mus., vol. 43, no. 1923, pp. 1-104, pls. 1-21.

Roxas, Hilario A. 1933. Philippine Alcyonaria. II. The families Alcyoniidae and Nephthyidae. Philipp. J. Sci., vol. 50, no. 4, pp. 345-470, pls. 1-5.

Sherifrs, W.R. 1922. Evolution within the genus Dendronephthya (Spongodes) (Alcyonaria), with descriptions of a number of species. Proc. Zool. Soc. Lond., 1922, pp. 33-77, pls. 1-3.

Thomson, J. A. and L. M. I. Dean 1931. The Alcyonacea of the Siboga Expedition, with an addendum to Gorgonacea. Siboga-Expeditie, monogr. 13d, livr. 115. 227 pp., 28 pls. Leiden.

Thomson, J. A. and D.L. Mackinnon 1910. Alcyonarians collected on the Percy Sladen Trust Expedition by Mr. J. Stanley Gardiner. Part II. The Stolonifera, Alcyonacea, Pseudaxonia and Stelechotokea. Trans. Linn. Soc. Lond, Zool., vol. 13, no. 8, pp. 168-211, pls. 6-14.

Thomson, J. A. and J. J. Simpson 1909. An account of the alcyonarians collected by the Royal Indian Marine Survey ship Investigator in the Indian Ocean. II. The alcyonarians of the littoral area. xviii +319 pp., 9 pls. Calcutta.

Tixier-Durivault, A. and M. Prevorsex 1960. Le genre Roxasia (Alcyonaria, Nephtheidae). Spolia Zool. Musei Hauniensis, vol. 18, pp. 1-296.

Uтіломт, H. 1954. Dentronephthya of Japan, II. New species and new records of Dendronephthya and the allied Stereonephthya from Kii region. Publ. Seto Mar. Biol. Lab., vol. 3, no. 3, pp. 319-338, pls. 39-40. 
Utinomi, H. 1958. A revision of the genera Nidalia and Bellonella, with an emendation of nomenclature and taxonomic definitions for the family Nidaliidae (Octocorallia, Alcyonacesa). Bull. Brit. Mus. (Nat. Hist.), Zool., vol. 5, no. 5, pp. 101-121.

1962. Preliminary list of octocorals of Sagami Bay deposited in the Biological Laboratory of the Imperial Household. Publ. Seto Mar. Biol. Lab., vol. 10, no. 1, pp. 105-108.

\section{POSTSCRIPT}

After this manuscript was submitted for publication early in 1966 I have received VerseVeldT's important paper published in Zool. Verhandelingen, No. 80 (1966), entitled as "Biological results of the Snellius Expedition, XXII. Octocorallia from the Malay Archipelago (Part II)". In this paper (p. 83-87, Text-fig. 46, pl. 13 fig. 1) VERSEVELDT described in detail distinctly branched colonies collected by the "Snellius" Expedition (1 ex.) and the "Siboga" Expedition (5 ex.) from the Malay Archipelago at the depths of 52-112 m. He recognized some distinct differences between these materials and THOMSON and MAckinnon's original description of Stereonephthya macrospiculata taken from Salomon Islands, 120-150 fms, but finally he identified them with the latter, as Thomson and Dean (1931) did. However, his conclusion seems to be inadmissible, as discussed above. 


\section{EXPLANATION OF PLATE XI}

Fig. 1. Coronephthya macrospiculata (Thomson and Mackinnon), comb. nov. Material collected at Amadaiba, east of Sagami Bay, $50 \mathrm{fms}$. and deposited in His Majesty's Biological Laboratory, registering as Coel. No. 57. $\times 2$

Fig. 2. Coronephthya macrospiculata (Thomson and Mackinnon), comb. nov. Material collected at Okinoyama, southeast of Sagami Bay, 85-90 m and deposited in His Majesty's Biological Laboratory, registering as Coel. No. 903.

Photo: Mr. Ch. Araga 
Publ. Seto Mar. Biol. Lab., XIV (3), 1966. PlATE XI

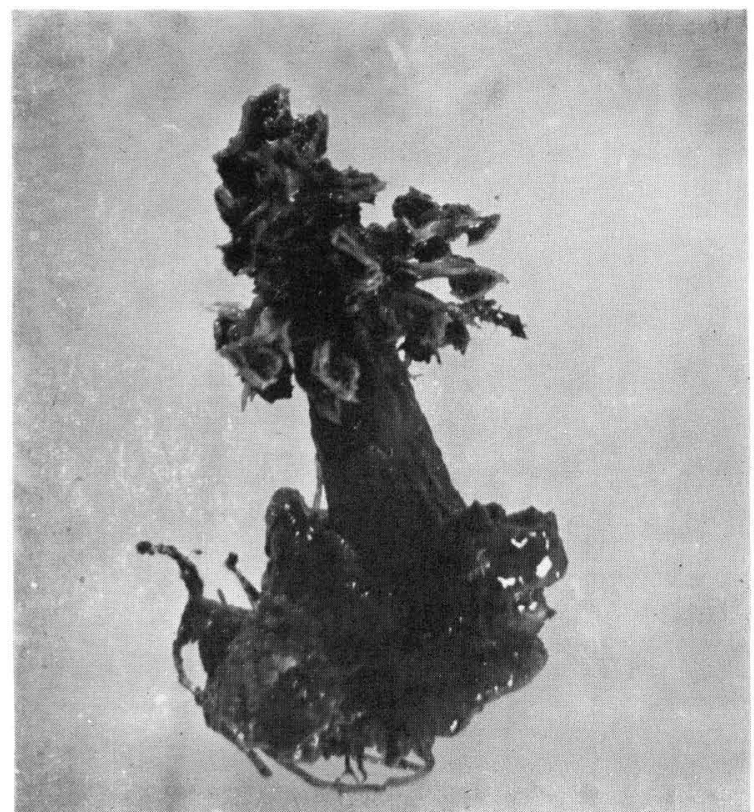

1

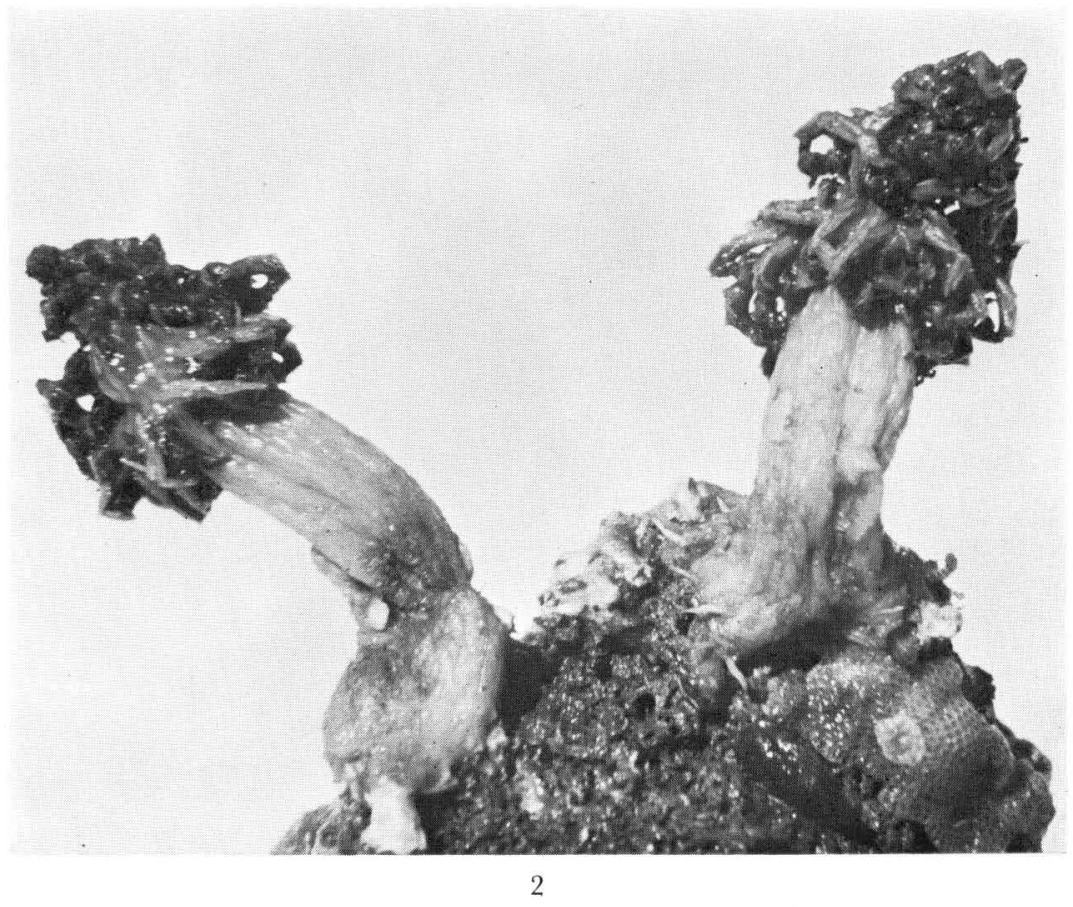

H. Utinomi : Revision of Nephtheidae, III. 